\title{
CADERNO DE MEMÓRIAS COLONIAIS E LUANDA, LISBOA, PARAÍSO: MULHERES NARRAM AS RUÍNAS DO IMPÉRIO
}

\author{
CADERNO DE MEMÓRIAS COLONIAIS AND \\ LUANDA, LISBOA, PARAÍSO: \\ WOMEN TELL THE RUINS OF THE EMPIRE
}

Rafaella Cristina Alves Teotônio ${ }^{1}$

\section{RESUMO}

Este ensaio pretende analisar como Caderno de Memórias coloniais (2015) e Luanda, Lisboa, Paraíso (2019), narrativas de Isabela Figueiredo e Djaimilia Pereira de Almeida, buscam abordar as duas faces de uma mesma história: a história da presença portuguesa na África. O trabalho busca discutir como as narrativas dessas duas autoras constroem, a partir das ruínas do Império, visões sobre o processo de colonização e descolonização, trazendo para a Literatura Portuguesa Contemporânea o debate acerca de temas como a nostalgia colonial, o racismo e a pós-memória.

PALAVRAS-CHAVE: Ruína. África. Racismo. Nostalgia colonial. Pós-memória.

\section{ABSTRACT}

This essay aims to analyze how Caderno de Memórias Coloniais (2015) and Luanda, Lisboa, Paraíso (2019), narratives by Isabela Figueiredo and Djaimilia Pereira de Almeida, seek to address the two sides of the same story: the history of the Portuguese presence in Africa. The work seeks to discuss how the narratives of these two authors build, from the ruins of the Empire, visions about the process of colonization and decolonization, bringing to contemporary Portuguese Literature the debate on themes such as colonial nostalgia, racism and the post- memory.

KEYWORDS: Ruin. Africa. Racismo. Colonial nostalgia. Post-memory. 
A Literatura Portuguesa Contemporânea, produzida no período pós-Revolução dos Cravos, buscou, nas memórias de autores que viveram na África, os traumas e experiências da colonização portuguesa. Essa extensa literatura que representa a África vai desde a experiência traumática das guerras pela libertação, revividas em romances como Os cus de Judas (2001), de Lobo Antunes e A costa dos murmúrios (1988), de Lídia Jorge, às obras que refletem sobre o processo de retorno dos portugueses que viviam nas colônias, como a conhecida obra de Dulce Cardoso, O retorno (2012). Nessas narrativas, a África é representada pelo olhar português, europeu, o olhar dos filhos do país colonizador, o que sugere, muitas vezes, uma visão de uma estadia em uma África traumática, mas também símbolo de um período de prosperidade financeira para muitos portugueses, um sonho de futuro. Recentemente, o tema dos retornados e da África ressurgiu de maneira significativa na Literatura Portuguesa com as obras de Isabela Figueiredo e de Djaimilia Pereira de Almeida. Com perspectivas diferentes, mas que se entrecruzam, as narrativas de Isabela e Djaimilia abordam a mesma África dos retornados portugueses e imigrantes africanos, vista pelos olhos de duas mulheres com histórias de vida e de migração diferentes.

Essas narrativas constroem o regresso das margens à pátria. Como elaborou Margarida Calafate Ribeiro (2004), no pós-25 de abril, além do fim da ditadura e da descolonização dos países africanos, houve, em Portugal, um processo de busca por repensar a nação, dessa vez a partir dos sujeitos que ficaram pelas margens, as partes desmembradas pelo regime salazarista. $\mathrm{Na}$ literatura, esse movimento de repensar Portugal, a partir das margens, proporcionou a representação de sujeitos antes ocultados ou narrativas que buscam revisitar as ruínas do Império, reimaginando a nação como um espaço de múltiplos sujeitos e múltiplas vozes.

Este ensaio procura refletir sobre as obras Caderno de memórias coloniais (2015) e Luanda, Lisboa, Paraíso (2019) como duas faces da mesma história, a história da colonização, revisitando as ruínas do Império a partir de memórias que traçam caminhos e corpos diferentes.

\section{REGRESSO À ÁFRICA DOS RETORNADOS}

A história das relações entre Portugal e África, seja sobre a guerra colonial, a descolonização ou a trajetória dos retornados, é feita por muitos olhares. Deveríamos então falar de histórias, assim, no plural, se quisermos caracterizar as múltiplas relações que compõem as identidades, as culturas e as histórias de Portugal e dos países africanos que, no século passado, foram suas colônias. O Império que ainda se apresenta na identidade portuguesa, seja nos monumentos, memória, símbolos e signos, custou caro aos portugueses. A colonização, a descolonização, a guerra colonial e a imensa massa de pessoas refugiadas nesse processo, hoje conhecidas como retornadas, deixaram para trás vidas, histórias e memórias. Mas não somente os tidos como retornados foram atingidos, milhares de famílias africanas foram fragmentadas e a sua diáspora constitui, hoje, em Portugal, uma presença que este país nem sempre quer aceitar. 
Poderíamos dividir essa História em duas histórias, dois olhares, duas partes de um Império que ruiu e cujos restos ainda se encontram vivos entre os escombros do que foi um dia uma glória, para muitos, e, para outros, uma maldição. As duas partes do Império podem ser encontradas em dois livros paradigmáticos para a Literatura Portuguesa Contemporânea: Caderno de Memórias Coloniais (2015), de Isabela Figueiredo e Luanda, Lisboa, Paraíso (2019), de Djaimilia Pereira de Almeida. De um lado, o retornado, desterrado ou refugiado, as memórias da filha do português que foi morar na colônia. Do outro, o filho do assimilado, o africano que vai para ex-Métropole em busca de acolhimento, mas apenas encontra desamparo e exclusão. Essas duas histórias, contadas pelos olhares de duas mulheres, revelam as duas faces de uma mesma história, dois restos, ruínas de um mesmo Império.

É nesse desdobrar de memórias que encontramos personagens similares nas duas narrativas, ambas histórias de famílias que se misturam a uma história coletiva, a da colonização e da descolonização. Em Caderno de Memórias coloniais (2015) e em Luanda, Lisboa, Paraíso (2019), a figura do pai é representativa para pensarmos como a colonização afetou de maneira diferente portugueses e africanos. De um lado, o pai de Caderno de Memórias Coloniais (2015) representa a colonização, a Metrópole e sua ânsia por explorar, não só a terra em que considera sua, mas os corpos dos homens que trabalham para ele e das mulheres que lhe dão prazer. A narrativa de Isabela Figueiredo é inspirada em sua própria experiência de filha de um português comum, trabalhador, que vai para Moçambique em busca de melhores condições de vida e encontra um paraíso no qual se sente dono, colono e, portanto, figura-metáfora para a imagem patriarcal da metrópole colonizadora. Do outro lado, em Luanda, Lisboa, Paraíso (2019), temos, na figura do pai, Cartola, a imagem do assimilado, o africano que participou do processo de assimilação como forma de ascender socialmente, mas que, ao chegar à ex-Métropole, descobre que nunca foi de fato parte dela, a não ser como colonizado.

Esses dramas familiares que se escoram na história coletiva são construídos pelas memórias dos filhos, pós-memórias que, como o próprio termo sugere, são memórias elaboradas a partir de outras memórias, as memórias dos pais e avós reconstituídas pela ótica dos filhos (SARLO, 2007). Tanto Djaimilia Pereira de Almeida quanto Isabela Figueiredo, em suas narrativas, fazem a mesma viagem, a da procura das identidades herdeiras dos processos coloniais. É por isso que ambos os livros, Caderno (2015) e Luanda, Lisboa, Paraíso (2019), trazem, em sua discursividade, a memória produzida por um eu que procura uma identidade em meio à experiência pós-colonial. Falamos não apenas do eu-autoral, as autoras, Isabela como filha de retornados, Djaimilia como filha de imigrantes, mas o eu que reconhecemos nos personagens, Cartola e seu filho Aquiles, dois angolanos desamparados à procura de si mesmos em Lisboa; ou a narradora de Caderno, a filha do pai colono que percebe, a partir das memórias da infância em Lourenço Marques, o racismo intrínseco nas relações da sua família com os africanos, percebendo-se parte do sistema colonial. 
Caderno de Memórias coloniais (2015) e Luanda, Lisboa, Paraíso (2019) são dois romances que falam de regressos e partidas. Podemos começar analisando o regresso, pela memória, à África colonial, a dos retornados. É a partir das memórias da narradora de Caderno que encontramos a África habitada pelos retornados. Como em muitas obras sobre o retorno, Isabela Figueiredo encontra na primeira pessoa a estratégia narrativa capaz de envolver o leitor em seu relato afetivo e familiar, mas, diferente de outros escritores que elaboram o "romance de retornados", o recurso melodramático da "vitimização do retornado" ou a busca por representar uma harmonia antes da guerra colonial (MACÊDO, 2020) dão lugar à desmontagem da nostalgia colonial. A representação de Moçambique pela memória de uma retornada, que se constrói no livro de Isabela Figueiredo, em nada se parece com a África apresentada em muitos relatos sobre a vida dos portugueses na colônia e, ao mesmo tempo, é a mesma vida relatada, agora analisada cruamente e sem a edição do olhar privilegiado dos colonos. Iniciando essa memória sem edições, resgatada da fantasia colonial, Caderno começa com uma ironia:

Manoel deixou o seu coração em África. Também conheço quem lá tenha deixado dois automóveis ligeiros, um veículo todo-o-terreno, uma carrinha carga, mais uma camioneta, duas vivendas, três machambas, bem como a conta no Banco Nacional Ultramarino, já convertida em meticais. (FIGUEIREDO, 2015, p. 37).

O trecho remonta à condição da partida dos portugueses e seus filhos no momento da descolonização. A partida da África com poucos pertences, o drama afetivo e material dos retornados tão explorado pela Literatura e mídia, a melancolia da perda pós-colonial, aqui, é pormenorizado por Figueiredo: "Quem é que não foi deixando os seus múltiplos corações algures?” (FIGUEIREDO, 2015, p. 37). Com esta ironia, Isabela Figueiredo busca dar um novo tom à história dos retornados, revelando que o apego material e afetivo pela África significava um apego pela condição privilegiada dos portugueses no contexto da colonização. A acidez das próximas passagens de Caderno mostra ao leitor a posição da autora perante a história dos retornados, em um trabalho de rememoração anti-nostálgico. O romance tratará do racismo nas relações entre colonos e nativos, deixando explícito o privilégio dos portugueses diante do aparato colonial que possibilitava as suas vivências nas colônias.

O pai é o símbolo para este aparato colonial. Na figura dele, a narrativa confunde a memória familiar, o trauma da filha com o trauma da nação. O pai era a metrópole a invadir o corpo da África, como o pai da narradora invade o corpo das "pretas":

Os brancos iam às pretas. As pretas eram todas iguais e eles não distinguiam a Madalena Xinguile da Emília Cachamba, a não ser pela cor da capulana ou pelo feitio da teta, mas os 
brancos metiam-se lá para os fundos do caniço, com caminho certo ou não, para ir à cona das pretas. Eram uns aventureiros. Uns fura-vidas. (FIGUEREIDO, 2015, p. 38).

O racismo das relações entre colonos e nativos, deixado de lado pelos vários relatos dos retornados, é analisado na narrativa pela relação do pai com as "pretas". O racismo dos homens brancos para com as mulheres negras nativas é a primeira lembrança da narradora acerca desta "África dos retornados". A partir da rememoração da narradora, percebemos como os homens brancos possuíam os corpos das mulheres negras como "aventureiros", em uma clara alusão à aventura colonial. Figueiredo remonta o olhar estigmatizado, fetichizado acerca das mulheres negras, tanto pelas mulheres brancas quanto pelos homens brancos, ao relatar a visão dos colonos que tornavam as mulheres negras animalizadas e selvagens, distinguindo-as das mulheres brancas:

Uma branca não admitia que gostasse de foder, mesmo que gostasse. E não admitir era uma garantia de seriedade para o marido, para a imaculada sociedade toda. As negras fodiam, essas sim, com todos e mais alguns, com os negros e os maridos das brancas, por gorjeta, certamente, por comida ou por medo. E algumas talvez gostassem, e guinchassem, porque as negras eram animais e podiam guinchar. Mas, sobretudo, porque as negras autorizavam-se a si próprias a guinchar, a abrir as pernas, a ser largas (FIGUEIREDO, 2015, p. 45-46).

Ao relatar esta visão racista dos colonos, Figueiredo expõe a relação de superioridade não só masculina, mas também racial, entre os portugueses e os africanos, desmistificando a África idílica e pacífica dos retornados.

Em uma das primeiras cenas do romance, a vida cotidiana em Lourenço Marques, hoje Maputo, traz a memória da nostalgia colonial das representações dos relatos dos retornados, mas, dessa vez, essa nostalgia é corrompida pelo sarcasmo da narradora que revela o racismo cotidiano nas relações entre portugueses e africanos:

Em Lourenço Marques, sentávamo-nos numa bela esplanada, de um requintado ou descontraído restaurante, tanto fazia, a qualquer hora do dia, a saborear o melhor uísque com soda e gelo e a debicar camarões, tal como aqui nos sentamos, à saída do emprego, num snack do Cais do Sodré, forrado a azulejos de segunda, engolindo uma imperial ou enjoando tremoços. Os criados eram pretos e nós deixávamos-lhe gorjeta se tivessem mostrado os dentes, sido rápidos no serviço e chamado patrão. Digo nós, porque eu estava lá, nenhum branco gostava de ser servido por outro branco, até porque ambos antecipavam a maior gorjeta. O meu pai, a quem coube a missão de eletrificar a Lourenço Marques desse tempo, nunca quis empregados brancos, porque teria de lhes pagar os olhos da cara (FIGUEIREDO, 2015, p. 47-48). 
A divisão social entre brancos e negros na colônia é ilustrada pela passagem do romance de Isabela Figueiredo. Brancos e negros não possuíam as mesmas posições sociais na África colonial, tendo o sujeito africano um lugar inferiorizado e brutalizado em sua própria terra. A rememoração do racismo cotidiano na sociedade de Lourenço Marques pela narradora de o Caderno de memórias coloniais (2015) desmonta o ambiente construído como paraíso pelos retornados e toca na ferida da colonização. Este racismo revelado pela narrativa de Figueiredo mostra como a estrutura da colonização, da qual os portugueses que moravam na colônia faziam parte, construía-se em torno do preconceito racial que mantinha os brancos em uma posição de superioridade, eles eram os "patrões":

"Em Moçambique era fácil um branco sentir prazer de viver. Quase todos éramos patrões, e os que não eram, ambicionavam sê-lo" (FIGUEIREDO, 2015, p. 50).

Esta passagem ilustra de forma precisa o que Grada Kilomba (2019) discorre sobre o racismo cotidiano, como um modo de construção do Outro-negro, pela projeção do sujeito branco: "No racismo cotidiano, a pessoa negra é usada como tela para projeções do que a sociedade branca tornou tabu. Tornamo-nos um depósito para medos e fantasias brancas do domínio da agressão ou da sexualidade" (KILOMBA, 2019, p. 78). Ao se sentir patrão, o colono branco projeta a sua fantasia no Outro-negro, colocando-o em um lugar de servidão e dependência:

Para esse fim, havia sempre muitos pretos, todos à partida preguiçosos, burros e incapazes a pedir trabalho, a fazer o que lhes ordenássemos sem levantar os olhos. De um preto dedicado, fiel, que tirasse o boné, dobrasse a espinha à nossa passagem, a quem se pudesse confiar a casa, as crianças, e deixar sozinho com os nossos haveres, dizia-se que era um bom mainato. Arranjava-se-lhe farda de caqui, chinelos, dava-se-lhe da nossa comida, comia na mesa do quintal ou na da cozinha, e quando a roupa do patrão ficava coçada, oferecíamos-lha como grande esmola. Ninguém queria perder um bom mainato (FIGUEIREDO, 2017, p. 50-51).

Enquanto o colono branco usufruía do privilégio que a sua cor e classe permitiam na Lourenço Marques colonial, o negro era colocado em uma posição de servidão que lhe objetificava e o tornava dependente do sistema colonial. Esse sentimento de se "sentir patrão" do colono português era o desejo de ser o que não eram na Metrópole, e atualizava, a partir da projeção no Outro-negro da sua indolência, o "pequeno colonizador" que existia em cada colono. A partir desta relação eu-Outro, entre colonos brancos e nativos negros, o racismo cotidiano se instala como um modus operandi do sistema colonial, capaz de manter a ordem colonial e construir o "bem estar" da vida dos colonos portugueses. 
O mecanismo do racismo exposto na narrativa de Caderno revela aquilo que muitos retornados não ousaram falar sobre suas vivências na África colonial, tocando na ferida ocultada por Portugal no contexto da independência dos países africanos nos anos 1960 e 1970 e, ainda, nos dias atuais. Eduardo Lourenço (2014), em seu ensaio Apelo ao(s) retornado(s), já apontara para a representação vitimizada do retornado como um modo de manter não apenas a nostalgia colonial, mas o mito da colonização portuguesa como uma colonização inocente:

O que aconteceu a cada retornado não lhe aconteceu a título de indivíduo, nem sequer a título de explorador com responsabilização privada numa colonização de súbito convertida pela tomada de consciência africana em colonialismo odioso, mas tão-só a título de actor anónimo de um longo processo histórico posto em causa por essa mesma tomada de consciência. Desta engrenagem o retornado não se queixa porque, fazendo parte dela, não lhe enxerga o mecanismo nem descortina a dose de fatalidade (para ele) que encerrava (LOURENÇO, 2014, p. 249),

Ao eximir-se da culpa, o sujeito retornado busca deslocar-se do rótulo de colonialista, ao focar no drama do retorno, elaborando, muitas vezes, uma África construída pelo trabalho português, longe do grande empreendimento colonial. Esta estratégia de negação pelo retornado, ao recusar a sua posição dentro do sistema colonial, remonta ao que Albert Memmi (2007) analisou como o sentimento de recusa a si mesmo que o "pequeno colonizador" elabora no contexto colonial: "O que ele recusa, de fato, se não uma parte de si mesmo, aquilo em que ele transforma lentamente quando aceita viver na colônia?" (MEMMI, 2007, p. 56).

A culpa por fazer parte do sistema colonial é expurgada na narrativa de Isabela Figueiredo e colabora com a desmontagem da nostalgia colonial que o romance propõe. A desmontagem colonial elaborada em Caderno revela como a identidade portuguesa foi construída a partir do discurso colonial, entre a imagem do Império e a imagem da Periferia, constituindo dois modos de se ver/entender a identidade portuguesa, que se misturam nas visões sobre o país. Eduardo Lourenço (2016) analisou de forma contundente esse aspecto, refletindo como a cultura portuguesa construiu-se em uma alteridade cuja colonização fazia com que os portugueses se sentissem grandes, mas longe de si mesmos:

Acontece, todavia, que mesmo na hora solar da nossa afirmação histórica, essa grandeza era, concretamente, uma ficção. Nós éramos grandes, dessa grandeza que os outros percebem de fora e por isso integra ou representa a mais vasta consciência da aventura humana, mas éramos grandes longe, fora de nós, no Oriente de sonho ou num Ocidente impensado ainda. (LOURENÇO, 2016, p. 28). 
A colonização, como também foi para muitos outros impérios, construía um ideal de grandeza que se escorava na nominação do colonizado como o Outro: o espelho que retornava, para o Império, a imagem do centro. Porém, para Portugal, esta ficção do Império não tinha consistência, no que corresponde às relações do país com os outros impérios europeus, e apenas matinha sua força longe, nas colônias. Nessa mesma perspectiva, Margarida Calafate Ribeiro (2004) observa como essa ambiguidade da identidade portuguesa, entre a imagem do Império e a imagem da Periferia, construía Portugal como uma "terra de fronteira". Ribeiro (2004) observa que a dialética colonial elaborada por Portugal era um modo de "imaginar-se como centro", fortalecendo uma imagem de grandeza perante a Europa:

Parece-me assim ser possível adiantar que as imagens de centro, construídas por Portugal, vêm rodeadas de fantasmas de periferia e que, de forma simétrica, as imagens de periferia estão frequentemente imbuídas de fantasias de centro. Assim, e para além das imagens de centro e periferia apontadas por Sousa Santos como resultado da nossa condição semiperiférica, insinuo aqui a existência de um complexo de imagens que irei definir como imagens de "império como imaginação do centro", e que refletem a condição pouco assumida, mas ansiosamente sentida por vários políticos e intelectuais, ora de Portugal como centro precário do império, ora mesmo como periferia imperial que, através do império, foi podendo imaginar-se como centro. (RIBEIRO, 2004, p. 6).

Para Ribeiro (2004), as imagens de Portugal refletem essa dinâmica que buscava na colonização uma forma de se posicionar como o centro, o rosto da Europa. Olhar o outro como um espelho é o movimento que emerge da cultura portuguesa e revela um desejo do outro, como afirmou Miguel Real (2017). Esse desejo tem relação com uma busca pelo outro como modo de afirmação de si mesmo, algo que se confunde com a busca colonial e com a projeção do sujeito branco no Outro-negro, abordada por Kilomba (2019). O desejo do Outro, segundo Real, converte-se também em "abertura ao outro" e "conversão do outro":

Assim, uma possível figuração da cultura portuguesa definir-se-ia por uma espécie de vazio do próprio, apenas satisfeito ou preenchido pelo desejo do que lhe está fora [...]. Segundo esta perspectiva, teríamos como corpo vital da cultura portuguesa um desejo do Outro expresso não neutralmente (por via de tratados, acordos, diplomacia), mas por via de uma ânsia de purificação e regeneração do Outro, da sua conversão missionária, o que António José Saraiva designa por "espírito ou mito de Cruzada" da cultura portuguesa, que, em diversos períodos da história de Portugal, sobretudo em momentos extremos da sua existência, se identificou mais com a salvação de si através da conversão do outro (mouro, índio, africano, chino, malaio...judeu) do que com a abertura plasmática ao outro. (REAL, 2017, p.180-181). 
Como demonstra o livro de Isabela Figueiredo, os colonos portugueses que viviam em Lourenço Marques espelhavam no Outro-africano a imagem colonial, mesmo recusando a si mesmos como sujeitos privilegiados pelo sistema colonial.

\section{EM BUSCA DO IMPÉRIO}

A memória da África colonial construída pelo olhar do retornado em Caderno de Memórias coloniais (2015) traz para o presente o passado colonial, restituindo, pela pós-memória, a lembrança acerca da vida dos portugueses na colônia. Essa lembrança, que antes era construída por um olhar saudoso e positivo, agora encontra uma visão traumática que reduz a memória nostálgica anterior a uma ruína. Mas a ruína, compreendida aqui como um resto do passado ainda presente, é, como elaboraram Roberto Vecchi e Ribeiro (2012, p. 97), "um testemunho do passado sem funcionalidade no presente, mas que pelo estudo, pela reconstrução, torna possível reapresentar o sentido da história”.

Ruína ainda presente na identidade portuguesa, a memória da colonização pela idealização nostálgica do passado se faz presente como "um legado macroscópico da experiência histórica de Portugal em África" (VECCHI, 2020, p.169). Este legado atenua a experiência dos portugueses na África, eliminando as marcas negativas e recriando uma África fantasmagórica no presente. Se a desmontagem dessa recriação idealizada da África é feita pela narrativa de Caderno, afirmando como ruína a memória da experiência portuguesa no continente africano, a narrativa de Luanda, Lisboa, Paraíso (2019), de Djaimilia Pereira de Almeida, busca encontrar, no presente, as ruínas que não se tornaram escombros.

A viagem de Luanda, Lisboa, Paraíso (2019) é inversa à de Caderno de memórias coloniais (2015). Enquanto a narrativa de Isabela Figueiredo busca, a partir do retorno, tornar as ruínas do Império escombros, Djaimilia Pereira de Almeida busca, em um tempo ainda presente, as ruínas que persistem. É na figura do assimilado, personagem pouco desenvolvido na Literatura Portuguesa, que Djaimilia encontra o outro lado da experiência portuguesa na África. A partir de Cartola, personagem assimilado que empreende uma viagem para Lisboa com seu filho, Aquiles, encontramos na narrativa o percurso contrário, a viagem do colonizado em busca do Império.

Luanda, Lisboa, Paraíso (2019) é uma narrativa que fala de uma busca, a busca do assimilado pelo Império que ruiu. Em outras palavras é a história de uma família que se separa por conta de um problema de saúde. Aquiles, filho de Cartola e Glória, nasce com uma deformidade no calcanhar e desde criança o pai espera levá-lo para Lisboa, afim de fazer uma cirurgia: "No hospital, depois de falsas partidas, sustos e adiamentos, explicaram ao pai que o calcanhar do filho teria conserto se ele fosse operado até aos quinze anos, o que aconteceria em 1985" (ALMEIDA, 2019, p. 12). Ao chegar na Metrópole, que já não é mais Império, Cartola e seu filho Aquiles encontram apenas frustração e desamparo: 
Ninguém os esperava no aeroporto, mas era Portugal. Cartola tinha em Lisboa um ou dois conhecimentos com quem se cruzara no passado. Fora um deles, um dr. Barbosa da Cunha, obstetra de Coimbra com quem trabalhara em Moçâmedes havia duas décadas, que intercedera junto da Embaixada por um quarto na Pensão Covilhã, à saída do Hospital Ortopédico do Alvor, onde se iniciariam os tratamentos ao calcanhar de Aquiles daí a um mês. Dentro do táxi, com o olhar curioso de duas crianças, viram Lisboa pela primeira vez. Pareceu-lhes pequena e escura. Caía uma chuva miudinha. Aquiles colou o nariz à janela do banco de trás e um coração feito com o dedo apareceu no vidro embaciado. (ALMEIDA, 2019 p. 27).

Para Cartola, a Lisboa que havia projetado no tempo da colonização não era a mesma que encontrara:

Tinha chegado a Lisboa tarde demais, depois de lhe ser possível domesticar a cidade. De cabeça, decalcava Lisboa por cima de Luanda: Sagrada Família-Mosteiro dos Jerónimos, Ilha-Cacilhas, Prenda-Prior Velho. Mas no interior de Cartola o mapa era ainda o mesmo. Caminhava sem referências. A nova cidade descarnada, sem arruamentos definidos, entontecia-o. Sentia as pernas tremer, perdia o equilíbrio, mesmo que soubesse estar perdido. Sabia ir do Campo Grande aos Restauradores, traçado que imaginara anos a fio como uma marcha triunfal. Aterrado em Lisboa, porém, a cidade não era como tinha projetado. Nada ficava perto de nada nem era tão imponente como nos postais ilustrados do passado. (ALMEIDA, 2019, p. 29-30).

Em Lisboa, Cartola se sente perdido, a Metrópole não era como havia imaginado. O Portugal que Cartola conhecia era o país que via nos postais e que se apresentava como Metrópole para os colonizados. A passagem de Luanda, Lisboa, Paraíso (2019) é a ilustração do imaginário inventado pela Europa no processo de colonização. Anibal Quijano (2005) reflete sobre essa invenção ao discutir como o Eurocentrismo, enquanto perspectiva de conhecimento, se estabeleceu a partir da colonização:

Contudo, os europeus persuadiram-se a si mesmos, desde meados do século XVII, mas sobretudo durante o século XVIII, não só de que de algum modo se tinham autoproduzido a si mesmos como civilização, à margem da história iniciada com a América, culminando uma linha independente que começava com a Grécia como única fonte original. Também concluíram que eram naturalmente (isto é, racialmente) superiores a todos os demais, já que tinham conquistado a todos e lhes tinham imposto seu domínio (QUIJANO, 2005, p. 127).

Essa lógica continua operando mesmo depois do fim político do colonialismo, enquanto uma colonialidade do poder, em que "as diferenças foram codificadas pela ideia de raça, estratégia dos conquistadores para estabelecer as relações que a dominação exigia” (QUIJANO, 2005, p.117). 
Nas cenas que abrem Luanda, Lisboa, Paraíso (2019), é possível compreender a busca de Cartola, a busca de um eu perdido no passado. $\mathrm{O}$ passado colonial, no qual Cartola, que se sentia jovem e importante trabalhando como parteiro em uma vida cheia de farturas herdadas do pequeno privilégio da assimilação, compartilhava com a esposa, Glória, saudosos do Império:

A sua memória tinha ficado presa ao Império como uma renda esgarçada a um alfinete. Talvez sonhasse que Cartola a levava a passear num Ford pela marginal ou que era hora de se encontrar com as amigas saindo de casa aperaltada: a única fula de luvas de renda e saltos de agulha admitida no Hotel da Ponte Branca. (ALMEIDA, 2019, p. 13).

A viagem de Cartola e Aquiles, aguardada desde a infância do filho, era mais que a busca de tratamento médico em Lisboa, mas a busca de Cartola a si mesmo, o Cartola do passado, e a busca de Aquiles por um futuro que sempre aguardara:

Oitenta e quatro, ano de que não se guardou memória, foi aquele em que Aquiles gastou cinco sebentas de papel-manteiga a desenhar e redesenhar Lisboa. O Tejo banhava a Baixa, fustigada por um dilúvio colorido a lápis de cera azul-vivo. Aqui e ali, avistavam-se porta-aviões desenhados ao pormenor a esferográfica. Além, um submarino era regido por espiões vietnamitas e, perto do lugar onde à escala ficaram as Avenidas Novas, uma longa linha de coqueiros sombreava famílias de passeantes em biquíni que piquenicavam à sombra entre cavalos brancos, ambulâncias, focos de incêndio e macacos com cara de homem. Os rascunhos, amarrotou-os e atirou-os para dentro de um jerricã esquecido na varanda da cozinha, que um dia a irmã encheu de água fazendo-os assomar como barquinhos naufragados. (ALMEIDA, 2019, p. 17).

Para Cartola e Aquiles, Lisboa era um sonho, um recomeço, mas a realidade que os cerca na chegada a Portugal demonstra que a expectativa acerca da ex-Metrópole não passava de uma ilusão. A viagem de pai e filho representa o percurso de muitos africanos no contexto da pós-colonização. Em decorrência das guerras e da situação econômica dos seus países, consequências dos processos de descolonização, muitos africanos partem para Portugal em busca da terra prometida, encontrando nos bairros periféricos seus lares, engrossando a massa de imigrantes que se amontoam no trabalho da construção civil. Cartola será um desses e Aquiles logo entenderá que o pai viera para Lisboa em busca de algo além do tratamento do seu calcanhar:

Um horizonte reabria-se para Cartola numa imensidão onde Aquiles não cabia. $\mathrm{O}$ homem que tinha à sua frente não era simplesmente um velho, como começara por lhe parecer no avião, mas um jovem em início de vida, um velho doente, nascido de novo. Aquiles abraçou o pai para o aquecer. Tremia de medo. "Poça, faz frio em Lisboa, Papá”. O pai, ensopado, estava quente por dentro. Tinha os lábios secos contornados num 
sorriso inocente. Quase dava para ver na cara dele o menino que um dia tinha sido. Aquiles soube que estava sozinho. Ele era o coxo e a bengala (ALMEIDA, 2019, p. 31-32).

Cartola de Sousa, o personagem assimilado, vive uma identidade presa ao passado colonial. Na narrativa de Luanda, Lisboa, Paraíso (2019), os anos de assimilação de Cartola e sua esposa Glória são descritos como uma fase perfeita, alheia ao que se passava na colônia com a luta pela independência em curso:

Nem o sono nem o acabrunhamento macularam o primeiro serão perfeito da vida dos Cartola de Sousa. As crianças brincavam com um cavalo de pau. As mulheres comentavam moldes de croché. No alpendre os homens fumavam e bebiam brandy aquecido enquanto o parteiro ia perdendo a vergonha de que o médico percebesse que lhe copiava as maneiras e o médico se satisfazia na presunção saborosíssima de se saber imitado. Vista da rua, na indolência da sua coreografia de silêncios, a cena era ao mesmo tempo bela e trágica, auspiciosa e tétrica. Através das cortinas de linho de duas janelas altas, as sombras dos quatro adultos eram a de quatro defuntos a dançarem numa moldura, numa casa a óleo, fora do tempo, para lá do lugar onde uma exceção pode salvar o que não tem de pedir desculpa por ser doce (ALMEIDA, 2019, p. 35-36).

Cartola e Glória viviam uma ilusão reforçada pela política de assimilação que vigorava nos países então colônias de Portugal. Nas colônias africanas, no período antecedente à independência, as políticas de assimilação propostas pelos países colonizadores tentaram apagar a cultura nativa e instituir uma identidade próxima à europeia, exaltando o preconceito contra os nativos, obrigando-os a incorporar a assimilação para não serem estigmatizados. Conforme Laura Cavalcanti Padilha (2005, p. 17) explica: "A assimilação, é bom não esquecer, era a única forma de o negro ter acesso a uma gama de direitos pelos quais ele podia ascender a uma condição apenas mediana de cidadania”. A estratégia de poder instaurada nas colônias tratava o sujeito africano como subordinado ao dominante europeu. Aníbal Quijano (2005) analisa esse processo de codificação do poder como uma tecnologia para sustentar a posição de dominação dos colonizadores:

Assim, cada forma de controle de trabalho esteve articulada com uma raça particular. Consequentemente, o controle de uma forma específica de trabalho podia ser ao mesmo tempo um controle de um grupo específico de gente dominada. Uma nova tecnologia de dominação/exploração, neste caso raça/trabalho, articulou-se de maneira que aparecesse como naturalmente associada, o que, até o momento, tem sido bem sucedido (QUIJANO, 2005, p. 119).

Com essa divisão do trabalho a partir da raça, a posição do sujeito colonizador nas colônias enquanto dominante era sustentada. Sobre a situação da colônia em meio a essa colonialidade do poder, José Luís Cabaço (2009) observa a determinação de um crescente processo de polarização 
em que duas sociedades diferenciadas, em Moçambique, a dominadora e a dominada, se relacionavam de forma opressora.

A sociedade colonial na África concebe-se e estrutura-se em consequência de uma multiplicidade de dualismos: frente a frente, bem demarcados, estarão não apenas "branco e preto", "indígena e colonizador", mas também "civilizado e primitivo", "tradicional e moderno", "cultura e usos e costumes", "oralidade e escrita", "sociedade com história e sociedade sem história", "superstição e religião", "código do trabalho indígena e lei do trabalho", "economia de mercado e economia de subsistência" etc., todos eles conceitos marcados pela hierarquização, em que uns se apresentam como negação dos outros e, em muitos casos, como a sua razão de ser (CABAÇO, 2009, p. 35).

Dessa forma, a marca da superioridade do colonizador se implantava na sociedade. Na sociedade colonizada, o africano, visto de forma desprezível nas relações sociais, não tinha chances de se desenvolver economicamente, pois os melhores empregos destinavam-se aos assimilados; os naturais da terra viam-se forçados à assimilação, mas isto não lhes garantia respeito, bem como não lhes rendia tratamento mais condizente com seu novo estatuto. A história dos Cartola de Souza representa o processo de assimilação como uma farsa que o nativo africano deveria desempenhar se quisesse ter uma posição social melhor, porém esta farsa é logo desmontada pela iminência da luta pela descolonização, fato que a família de Cartola se recusa a enfrentar:

Os primeiros cinco anos de vida da criança apanharam a família no cruzamento entre a crescente paralisia da mãe Glória e a iminência da Independência. Cartola passou essa meia década à cabeceira da mulher, que piorava. Evitava a política como se evitasse um vagabundo na rua, a ponto de estar capaz de confundir uma granada com a bomba de medir a pressão arterial. De cama desde o início de setenta, Glória conservava algures dentro dela a memória do que haviam sido anos de uma assimilação próspera (ALMEIDA, 2019, p. 12-13).

A doença que deixa Glória paralisada em uma cama é a paralisia da família diante do novo país que surgia, distante de Portugal e da sua política de assimilação. Encerrado em um passado colonial que já não mais existe, ao partir para Lisboa com o filho, Cartola espera encontrar no país lusitano a promessa que a assimilação deixou para si, a de ser também um cidadão português:

Parecia pensar que um dia lhe bateriam à porta e lhe diriam que estava tudo tratado, que era enfim português, direito que julgava pertencer-lhe. Não sabia ele conjugar o gerundivo e a origem etimológica da palavra "Tejo"? Não achava, inspecionando-se ao espelho, que não se geravam a norte do Alentejo, "e muito menos em África", maças-de-adão como a de Aníbal Cavaco Silva? Não era dócil e cordato contando que não estivesse bebido? Não engraxava os sapatos do filho 
aos domingos sentindo-se mortificado? Não escolhera já o seu talhão no cemitério dos prazeres, para onde se esquivava a entoar cânticos fúnebres em kikongo enquanto admirava os jazigos de famílias? Não se arrepiava ao ouvir o hino de Portugal e sabia de cor a primeira estrofe dos Lusíadas? (ALMEIDA, 2019, p. 74).

Cartola é a representação fantasmática de um Império que ruiu, mas suas ruínas continuam presentes, um passado que persiste mesmo parecendo morto. Sua existência enquanto imigrante é a ruína do Império. $\mathrm{Na}$ cena em que o personagem vagueia pelo cemitério dos Prazeres, a sensação fantasmática do personagem é enfatizada. Ao olhar os túmulos, Cartola se sentiu em paz, longe dos tropeços com a língua portuguesa e da sensação de deslocamento que vivia no resto da cidade. Ali desejou também sua morte e um final tranquilo, naquele cemitério, os mortos "eram por umas horas os seus únicos iguais na cidade das sete colinas" (ALMEIDA, 2019, p. 80).

Em Luanda, Lisboa, Paraíso (2019), o Paraíso é a periferia que assoma os milhares de sujeitos africanos, herdeiros dos processos coloniais, que, como Cartola, marcham sem sentido em uma Metrópole que os marginaliza. São esses sujeitos que constroem as cidades europeias, mexendo nas ruínas de um passado que se reatualiza através dos espaços, monumentos, museus, culturas, migrações. Não é por acaso que Djaimilia Pereira de Almeida nomeia o bairro fictício onde Cartola e Aquiles se instalam, assim como outros africanos e periféricos em Lisboa, de Paraíso, remetendo ao imaginário colonial europeu sobre o Oriente. Nas narrativas que constroem esse imaginário, o Oriente e todo o mundo não-europeu é visto como um lugar onde os europeus, em suas aventuras coloniais, encontram a sua Ilha dos Amores, um mundo onde a riqueza, a beleza e o desconhecido confundem-se no signo ambíguo da colonização. A escolha do nome Paraíso é irônica, pois este mundo envolto de misticismo pelo olhar europeu só se tornou um "paraíso" para os próprios europeus. Lugar onde a Europa buscava o ouro e o espelho que construía a sua pretensa superioridade.

Nas narrativas de Caderno de Memórias Coloniais (2015) e Luanda, Lisboa, Paraíso (2019), as histórias de retornados, imigrantes, africanos e portugueses se encontram, trançando um novo mapa para Portugal, repensado a partir das margens. A presença ex-cêntrica se faz cada vez mais nítida no Romance Português Contemporâneo, não apenas como um traço do que alguns pesquisadores chamam de "Romance Pós-Moderno ou pós-revolucionário", mas como a realidade de um país representada pela sua literatura.

\section{REFERÊNCIAS}

ALMEIDA, Djaimilia Pereira de. Luanda, Lisboa, Paraíso. São Paulo: Companhia das Letras, 2019.

ANTUNES, António Lobo. Os cus de Judas. 21. ed. Lisboa: Dom Quixote, 2001. 
CABAÇO, José Luís. Moçambique: identidade, colonialismo e libertação. São Paulo: Editora, UNESP, 2009.

CARDOSO, Dulce Maria. O retorno. Lisboa: Tinta da China, 2012.

FIGUEIREDO, Isabela. Caderno de Memórias Coloniais. Alfragide: Editorial Caminho, 2015.

JORGE, Lídia. A Costa dos Murmúrios. Lisboa: Dom Quixote, 1988.

KILOMBA, GRADA. Memórias da Plantação: episódios de racismo cotidiano. Tradução Jess Oliveira. Rio de Janeiro: Cobogó, 2019.

LOURENÇO, Eduardo. Do colonialismo como nosso impensado. (orgs.) RIBEIRO, Margarida Calafate. VECHI, Roberto. Lisboa: Gradiva, 2014.

LOURENÇO, Eduardo. O labirinto da saudade. Rio de Janeiro: Tinta da China, 2016.

MACÊDO, Tania. O Romance Português de Retornados: a viagem de retorno ao Império colonial português. In: Mulemba. Rio de Janeiro. Volume 12. Número 22. Jan/Jun 2020.

MEMMI, Albert. Retrato do colonizado precedido de Retrato do colonizador. Tradução de Marcelo Jacques de Moraes. Rio de Janeiro: Civilização Brasileira, 2007.

PADILHA, Laura Cavalcante. Da construção identitária a uma trama de diferenças - Um olhar sobre as literaturas de língua portuguesa. Revista Crítica de Ciências Sociais, 73, dez. 2005, p. 3-28.

QUIJANO, Anibal. Colonialidade do poder, Eurocentrismo e América Latina. In: A colonialidade do saber: eurocentrismo e ciências sociais. Perspectivas latino-americanas. Buenos Aires: CLACSO, Consejo Latinoamericano de Ciencias Sociales, 2005, p. 117-142.

REAL, Miguel. Traços fundamentais da cultura portuguesa. Lisboa: Planeta, 2017.

RIBEIRO, Margarida Calafate. Uma história de regressos: Império, Guerra Colonial e Pós-colonialismo. Porto: Afrontamento, 2003.

SARLO, Beatriz. Tempo Passado: Cultura da Memória e Guinada Subjetiva, São Paulo: Companhia das Letras, Belo Horizonte: UFMG, 2007.

VECCHI, Roberto. A nostalgia colonial no país da saudade: fantasmagorias e pós-memória. In: Confluenze. Vol XII, N.2, 2020.

VECCHI, Roberto. RIBEIRO, Margarida Calafate. A memória poética da guerra colonial de Portugal na África: os vestígios como material de uma 
construção possível. In: SEDLMAYER, Sabrina. GUINZBURG, Jayme. (orgs.) Walter Benjamim: rastro, aura e história. Belo Horizonte: Editora UFMG, 2012.

Recebido para avaliação em 27/05/2021

Aprovado para publicação em 28/06/2021

\section{NOTAS}

1 É doutora em Teoria da Literatura pelo Programa de Pós-Graduação em Letras da Universidade Federal de Pernambuco e mestre em Literatura e Interculturalidade pelo Programa de Pós-graduação em Literatura e Interculturalidade da Universidade Estadual da Paraíba. Atualmente é professora adjunta de Literaturas em Língua Portuguesa na Universidade de Pernambuco (UPE - Campus Mata Norte), sendo também pesquisadora do Centro de Estudos Linguísticos e Literários da UPE - CELLUPE. 